\title{
DETERMINAN INTERNAL KEMAMPULABAAN PERBANKAN INDONESIA (STUDI EMPIRIS PADA PERBANKAN UMUM KONVENSIONAL YANG TERDAFTAR DI BEI TAHUN 2011-2016)
}

\author{
Cindy \\ Program Study Magister Akuntansi Fakultas Ekonomi \\ Universitas Tarumanagara, Jakarta \\ Email: ctheoville@gmail.com
}

\begin{abstract}
The purpose of this research is to analyze and prove empirically the quality of productive assets (NPL), company size (Natural logarithm of total asset), liquidity (LDR), capital adequacy (CAR), and efficiency level (BOPO) as an internal determinant of profitability with RoRWA and ROA indicators on banks in Indonesia. Samples of 31 banks listed on the Indonesia Stock Exchange for Conventional Commercial Banks in Indonesia year 2011-2016. Data was analyzed using Structural Equation Modelling (SEM) with SmartPLS software version 2.0. The result of this study indicates that the quality of productive assets, company size, and capital adequacy affect profitability positively, while liquidity and efficiency affect profitability negatively.
\end{abstract}

Keywords : Profitability, The Quality of Productive Assets, Firm Size, Liquidity, Capital Adequacy, Efficiency

\begin{abstract}
ABSTRAK
Tujuan dilakukannya penelitian ini adalah untuk menganalisis dan membuktikan secara empiris kualitas aset produktif $(N P L)$, ukuran perusahaan (Ln total aset), likuiditas ( $L D R)$, kecukupan modal $(C A R)$, dan tingkat efisiensi (BOPO) sebagai determinan internal kemampulabaan dengan indikator RoRWA dan ROA pada perbankan di Indonesia. Sampel yang diambil sebanyak 31 bank yang terdaftar di Bursa Efek Indonesia untuk data Perbankan Umum Konvensional di Indonesia tahun 2011-2016. Data dianalisis menggunakan program Structural Equation Modelling (SEM) dengan software SmartPLS versi 2.0. Hasil dalam penelitian ini menunjukkan bahwa kualitas aset produktif, ukuran perusahaan, dan kecukupan modal berpengaruh positif terhadap kemampulabaan, sedangkan likuiditas dan tingkat efisiensi berpengaruh negatif terhadap kemampulabaan.
\end{abstract}

Kata Kunci: kemampulabaan, kualitas aset produktif, ukuran perusahaan, likuiditas kecukupan modal, dan tingkat efisiensi

\section{PENDAHULUAN \\ Latar Belakang}

Di Indonesia perbankan terus mengalami perkembangan struktural. Kondisi perbankan Indonesia tidak diatur secara jelas oleh Undang-Undang pada tahun 1980. Perbankan di Indonesia mengalami penurunan kinerja. Kredit macet yang semakin meningkat, rendahnya likuiditas bank, serta peraturan tentang tingkat kesehatan bank yang sulit diterapkan merupakan hal-hal penyebab memburuknya kondisi perbankan di Indonesia pada saat itu. Salah satu hal penting yang disorot adalah kecukupan modal pada bank. Oleh karena peranan bank yang sangat vital bagi perekonomian suatu negara maka perbankan dipaksa agar lebih kompetitif serta peraturan-peraturan dalam penilaian tingkat kesehatan bank diterapkan dengan ketat dan dapat diukur pula dengan kemampulabaan sebuah perbankan. Istilah kemampulabaan diartikan sebagai kemampuan perusahaan untuk memperoleh laba dan potensi untuk memperoleh penghasilan pada masa yang akan datang (www.bi.go.id dan Ralona M., 2006).

Indikator kesehatan industri perbankan seperti Return on Risk-Weighted Assets (RoRWA), Return On Assets (ROA), Loan to Deposits Ratio (LDR), dan Capital Adequacy Ratio $(C A R)$ mengalami fluktuasi dari tahun ke tahun. Rasio keuangan Return on Risk- 
Weighted Assets (RoRWA) dan Return On Assets (ROA), kedua rasio ini merepresentasikan tentang kemampulabaan bank. Terdapat dua faktor determinan yang mempengaruhi kemampulabaan, yaitu faktor internal dan eksternal. Determinan internal yang dihasilkan dari keputusan dan kebijakan manajemen bank dapat mempengaruhi aktivitas operasional bank termasuk kemampulabaan yang terdiri dari kecukupan modal, risiko kredit, likuiditas, bank size, dan manajemen pengeluaran.

Penelitian-penelitian terdahulu yang dilakukan pada beberapa negara menghasilkan kesimpulan beberapa faktor yang berdampak pada kemampulabaan sebuah perbankan, baik itu faktor dari internal maupun eksternal perbankan diantaranya adalah kualitas aset produktif yang diproksikan dengan NPL berpengaruh negatif terhadap kemampulabaan. Selain $N P L$, ukuran perusahaan juga berpengaruh dalam menentukan kemampuan sebuah perusahaan dalam mendapatkan laba yang besar. Penyaluran kredit yang baik juga menunjang sebuah bank dalam mendapatkan laba, namun apabila terdapat banyak kredit yang bermasalah, akan menimbulkan kecemasan apakah bank tersebut dapat mempertahankan labanya atau bahkan dapat mengalami kerugian. Kecukupan modal sebuah perbankan juga dibutuhkan, dimana sebuah bank dapat dikatakan baik apabila telah memenuhi persentase $C A R$ tertentu, sehingga mampu untuk menjaga stabilitas perbankan dan meningkatkan laba. Tak hanya dari sisi neraca yang patut diperhitungkan dalam pencarian laba sebuah bank, tetapi juga kemampuan manajemen dalam melakukan pengelolaan terhadap sumber daya dan melakukan efisiensi terhadap biaya-biaya dan mampu meningkatkan pendapatan. Apabila biaya yang ditimbulkan terlalu besar, namun pendapatan yang didapat rendah, maka hal ini akan menambah buruk kondisi keuangan perbankan. Kurangnya penelitian yang menggunakan RoRWA sebagai proksi dari kemampulabaan yang pada umumnya kemampulabaan diukur dengan menggunakan $R O A$ ataupun $R O E$, hal ini menarik perhatian penulis untuk melakukan penelitian lebih lanjut mengenai kemampulabaan yang diproksikan dengan RoRWA, namun dalam penelitian ini, penulis menggunakan dua pengukuran dalam kemampulabaan, yaitu RoRWA dan ROA.

\section{Rumusan Masalah}

Seluruh makalah yang dikirimkan harap tetap menyertakan nomor halaman, dan header dan footer yang ada. Mohon header pada halaman genap disesuaikan judul makalah dan nama penulis. Jika nama penulis lebih dari satu, tambahkan "et al" untuk menggantikan nama penulis kedua dst.

\section{Kajian Teori}

Basel merupakan hasil rekomendasi dan pedoman yang dikeluarkan oleh Basel Committee on Banking Supervision (BCBS) yang menjadi acuan bank sentral di lebih dari 100 negara. Basel I, diterbitkan pada tahun 1988 dan diadopsi oleh Bank Indonesia (BI) pada tahun 1993 dimana mengatur minimum permodalan perbankan atas dasar risiko kredit, yang dihitung dari Aktiva Tertimbang Menurut Risiko (ATMR). Pada tahun 2004 basel II diterbitkan dan diadopsi oleh BI pada tahun 2008, basel II diterbitkan untuk merevisi basel I dengan memperkenalkan sistem 3 pilar, yaitu: pilar 1 mengatur mengenai Kebutuhan Penyediaan Modal Minimum (KPMM) untuk menutup risiko kredit, risiko pasar (trading book), dan risiko operasional. Pilar 2 mengatur masalah pengawasan oleh regulator, dimana bank wajib menunjukkan bahwa bank memiliki kemampuan mengendalikan berbagai macam risiko pada operasional sehari-hari. Pilar 3 mengatur kewajiban bank untuk memberitahukan secara transparan pada masyarakat, mengenai metode yang digunakan untuk mengendalikan risiko. Basel III, timbul sebagai bentuk pembaharuan dari basel II, dikarenakan adanya krisis global tahun 2008-2009. Pada basel 
III, sistem 3 pilar dari basel II tetap berlaku dengan menambahkan beberapa fokus pada kualitas modal, likuiditas, masalah pro-cyclicality (kejadian berulang di mana pada saat ekonomi sedang tumbuh, bank cenderung terlalu longgar dalam ekspansi kredit, sebaliknya pada kondisi buruk, bank terlalu ketat dalam mengucurkan kredit) dan masalah sistemik (permasalahan pada satu bank dapat dengan mudah merembet pada bank lain). Penilaian tingkat kesehatan bank yang termuat dalam Surat Edaran Kepada Semua Bank Umum yang Melaksanakan Kegiatan Usaha Secara Konvensional di Indonesia No.6/23/DPNP tanggal 31 Mei 2004 mencakup penilaian terhadap faktor-faktor CAMELS (permodalan, kualitas aset, manajemen, rentabilitas, likuiditas, sensitivitas terhadap risiko pasar).

Kinerja suatu bank dapat diukur dengan kemampulabaan. Kemampulabaan merupakan wujud dari kemampuan bank untuk menghasilkan keuntungan pada periode tertentu. Kemampulabaan yang sehat dan berkelanjutan merupakan hal yang sangat dibutuhkan dalam mempertahankan stabilitas perbankan (Idris et al., 2011). Salah satu indikator bahwa usaha bank tersebut telah berjalan efisien atau tidak dapat diketahui dengan membandingkan laba yang diperoleh dengan aset yang menghasilkan laba tersebut. Indikator dari kemampulabaan yang banyak digunakan adalah Return on Assets (ROA) hal ini terlihat dari penelitian Almazari (2014), Rahman et al. (2012), Javaid et al. (2011), Idris et al. (2011), Merin (2016), serta Schiniotakis (2012) yang menggunakan ROA sebagai indikator dari kemampulabaan. ROA yang dirumuskan oleh SE BI 13/30/DPNP 16 Desember 2011 sebagai berikut: $R O A=$ (Laba Sebelum Pajak / Rata-rata Total Aset). Kemampulabaan dapat dihitung juga dengan menggunakan Return on Risk Weighted Assets (RoRWA). RoRWA lebih dapat memberikan panduan yang optimal tentang kinerja bank dalam beberapa dimensi, yaitu: RoRWA dapat menilai seberapa baik bank mengelola neraca dan risikonya, menjadi tolok ukur pengambilan keputusan tentang risiko dan peluang, dan RoRWA menekankan biaya risiko dengan mengungkapkan seberapa baik bank dapat meminimalkan ketentuan pemberian pinjaman dengan dasar risiko (Sinn, D’Acunto, dan Oldrini, 2013). RoRWA yang dirumuskan oleh Brie dan Freon (2011) sebagai berikut: RoRWA = (Laba Sebelum Pajak / Aktiva Tertimbang Menurut Risiko). Sehingga dalam penelitian ini menggunakan dua indikator dalam pengukuran kemampulabaan, yaitu ROA dan RoRWA.

Kualitas aset produktif yang direpresentasikan dengan indikator rasio keuangan $N P L$ dengan cara membandingkan kredit bermasalah terhadap total kredit yang disalurkan (Alper dan Anbar, 2011). Bank Indonesia mengkategorikan kredit atau pembiayaan bermasalah dengan kurang lancar, diragukan, dan macet. Nilai NPL yang tinggi memiliki arti kualitas pembiayaan perbankan yang buruk. Selain itu, tingginya $N P L$ menunjukan bahwa bank tersebut tidak profesional dalam mengelola pemberian kreditnya dan menggambarkan tingkat risiko kredit yang tinggi. Ukuran perusahaan yang dihitung dengan menggunakan Ln dari total aset, didasari dari beberapa penelitian yang dilakukan, diantaranya adalah di Pakistan oleh Riaz dan Mehar (2013), Rahman et al. (2012), Javaid et al. (2011), Ali, Akhtar, dan Ahmed (2011), di negara Eropa oleh Menicucci dan Paolucci (2015), serta di negara China oleh Tan, Floros, dan Anchor (2016). Penelitian yang dilakukan di Sri Lanka, menemukan bahwa dengan nilai aset yang besar, maka sebuah perbankan dapat melakukan ekspansi atau perluasan usaha mereka dengan membuka banyak kantor cabang di wilayah lain, sehingga hal ini meningkatkan pendapatan perbankan tersebut dan meningkatkan laba (Yamuna, 2013). Likuiditas menunjukkan bagaimana perusahaan dapat memenuhi kewajiban jangka pendeknya. Sedangkan rasio risiko finansial menunjukkan kemampuan perusahaan untuk memenuhi keseluruhan kewajiban dan dampak dari kewajiban-kewajiban tersebut pada struktur neraca. $L D R$ menunjukkan kemampuan bank dalam membayar kembali penarikan dana 
yang dilakukan oleh deposan dengan mengandalkan kredit yang diberikan sebagai sumber likuiditasnya. Semakin rendah rasio ini memberikan indikasi semakin baik kemampuan likuiditas bank yang bersangkutan. Hal ini disebabkan karena bank tersebut mampu menyalurkan kreditnya secara optimal. Berdasarkan Surat Edaran Bank Indonesia No. 6/23/DPNP Tahun 2004 tentang kriteria penetapan peringkat profil risiko, kriteria yang sangat sehat apabila nilai $L D R \leq 75 \%$, dan hasil terparah tidak sehat apabila nilai $L D R>$ $120 \%$. Semakin rendah $L D R$ berarti juga laba bank semakin meningkat, dengan asumsi bahwa bank tersebut mampu menyalurkan kreditnya dengan efektif. Pada penelitian yang dilakukan di Albania kompetisi untuk mendapatkan nilai deposit yang tinggi dilakukan dengan cara memberikan bunga yang lebih tinggi, sehingga nilai deposit meningkat. Banyak bank di Albania melakukan ini karena nilai deposit dianggap sebagai pembiayaan yang murah dan tergolong stabil, sehingga hasil penelitian di Albania menunjukkan hasil yang positif antara likuiditas dengan kemampulabaan (Duraj dan Moci, 2015). Namun apabila bank tidak mampu menyalurkan kreditnya dengan baik, akan menimbulkan kredit macet dikemudian hari, sehingga akan menambah beban bagi kredit yang bermasalah tersebut dan pada akhirnya akan mengurangi laba bagi perbankan (Idris et al., 2011). Dalam melakukan penilaian kecukupan permodalan, terdapat keterkaitan antara kecukupan modal dengan profil risiko. Keterkaitan tersebut adalah semakin besar modal yang disediakan untuk mengantisipasi risiko yang ada akan berpengaruh terhadap rendahnya peringkat profil risiko di dalam perbankan. Dengan kata lain, semakin besar $C A R$ maka profil risiko akan semakin rendah. apabila sebuah bank memiliki modal yang lebih, maka bank tersebut dapat dengan mudah memenuhi persyaratan perbankan yang dianjurkan oleh pemerintah, sehingga kelebihan modal yang tidak digunakan dalam operasional dapat diberikan sebagai pinjaman, kecukupan modal yang dihitung dengan indikator $C A R$, dianggap mampu untuk menunjukkan kesehatan sebuah perbankan (Ani et al., 2012). bank yang memiliki modal yang cukup dianggap relatif lebih aman dan kurang beresiko, sehingga mampu untuk mengurangi biaya pendanaannya Bougatef (2015). Bank dengan modal yang cukup juga mampu bertahan disaat krisis, sehingga bank-bank yang mampu bertahan yang lebih dipercaya masyarakat dan dibanyak digunakan oleh masyarakat (Ongore dan Kusa, 2013). Tingkat efisiensi perbankan dengan indikator BOPO yang merupakan rasio dengan perhitungan beban operasional dibagi pendapatan operasional, sehingga apabila persentase yang didapat semakin tinggi, maka hasil yang disimpulkan adalah bank tersebut tidak efisien, apabila sebuah bank tidak efisien, maka dalam mengelola operasional bank tersebut dianggap tidak juga mampu menghasilkan pendapatan, sehingga laba yang dihasilkan kecil atau bahkan tidak memiliki laba (Ali, Akhtar, dan Ahmed, 2011, Bougatef, 2015, serta Tan, Floros, dan Anchor, 2016). Hasil penelitian ini sekaligus membuktikan adanya perbedaan dengan hasil penelitian lain yang menyatakan efisiensi operasional bank mempengaruhi positif signifikan kemampulabaan, hal ini dikarenakan selain dengan menggunakan indikator BOPO, efisiensi juga dapat diukur dengan rasio laba terhadap pendapatan dan adanya faktor kualitatif melalui evaluasi subjektif dengan sistem manajemen, disiplin organisasi, sistem pengendalian dan kualitas staf (Samad, 2015 serta Ongore dan Kusa, 2013).

Kerangka pemikiran dalam penelitian ini seperti digambarkan berikut ini: 


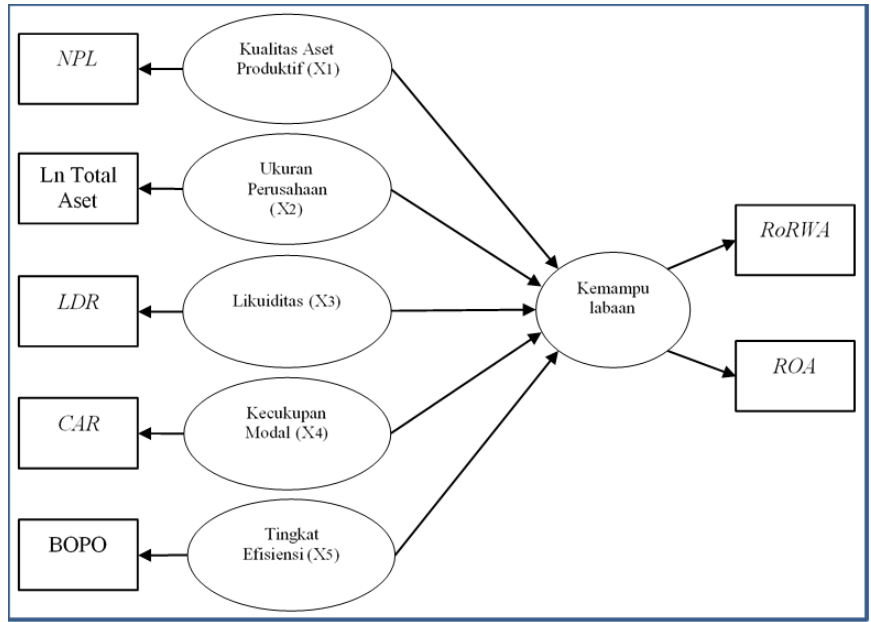

Gambar 1.

Kerangka Pemikiran

Sumber: Data Olahan Penulis (2017)

Berdasarkan literatur penelitian yang telah dipaparkan sebelumnya, maka hipotesis penelitian ini adalah sebagai berikut:

Ha1 = Kualitas aset produktif dengan indikator NPL mempengaruhi negatif kemampulabaan dengan indikator RoRWA dan ROA.

Ha2 = Ukuran perusahaan dengan indikator Ln Total Aset mempengaruhi positif kemampulabaan dengan indikator RoRWA dan $R O A$.

$\mathrm{Ha} 3=$ Likuiditas dengan indikator $L D R$ mempengaruhi positif kemampulabaan dengan indikator RoRWA dan ROA.

Ha4 = Kecukupan modal dengan indikator $C A R$ mempengaruhi positif kemampulabaan dengan indikator RoRWA dan ROA.

Ha5 = Tingkat efisiensi dengan indikator BOPO mempengaruhi negatif kemampulabaan dengan indikator RoRWA dan ROA.

\section{METODE PENELITIAN}

Desain yang digunakan adalah desain konklusif (conclusive research design), dalam penelitian digunakan pendekatan deskriptif pada penelitian konklusif. Populasi dalam penelitian ini adalah perusahaan perbankan yang terdaftar di Bursa Efek Indonesia (BEI) pada periode 2011-2016. Data yang digunakan dalam penelitian ini berupa data panel dengan teknik pengambilan sampel dengan menggunakan kriteria tertentu yang telah ditentukan untuk mendapatkan sampel sesuai dengan tujuan yang sudah ada. Berikut ini merupakan kriteria-kriteria dalam pengambilan sampel, yaitu perbankan yang terdaftar pada periode 2011-2016, perbankan menyajikan laporan keuangannya dalam website BEI selama periode 2011-2016, perbankan yang menyajikan laporan keuangannya dalam mata uang Rupiah, perbankan yang memiliki jenis Bank Umum Konvensional.

Jumlah data yang memenuhi syarat untuk diteliti sebanyak 31 perusahaan.

Variabel operasional dalam penelitian ini terdiri dari variabel dependen / variabel endogen, yang terdiri dari kemampulabaan yang diukur dengan indikator RoRWA dan $R O A$, variabel independen / variabel eksogen, yang terdiri dari kualitas aset produktif yang diukur dengan $N P L$ (X1), ukuran perusahaan yang diukur dengan total aset (X2), likuiditas yang diukur dengan $L D R$ (X3), kecukupan modal yang diukur dengan $C A R$ (X4), dan tingkat efisiensi yang diukur dengan BOPO (X5). Indikator yang digunakan untuk variabel kualitas aset produktif adalah rasio $N P L$, yaitu besarnya risiko kredit 
bank dibandingkan dengan total kredit, dengan rumus: NPL $=$ Kredit Bermasalah / Total Kredit. Indikator yang digunakan untuk variabel ukuran perusahaan adalah logaritma natural (Ln) dari total aset. Tujuan dari logartima natural (Ln) dari total aset agar hasil Ln total aset tidak berbeda jauh nilainya dengan variabel lainnya dan hasilnya juga tidak bias, dengan rumus: Ukuran Perusahaan $=$ Ln (Total Aset). Indikator yang digunakan untuk variabel likuiditas dihitung dengan $L D R$, dengan rumus: $L D R=$ Kredit $/$ Dana Pihak Ketiga. Indikator yang digunakan untuk variabel kecukupan modal diukur menggunakan $C A R$, dengan rumus: $\mathrm{CAR}=$ Modal Bank / Aktiva Tertimbang Menurut Risiko. Indikator yang digunakan untuk variabel tingkat efisiensi diukur dengan Biaya Operasional terhadap Pendapatan Operasional (BOPO), dengan rumus: $\mathrm{BOPO}=$ Total Beban Operasional / Total Pendapatan Operasional.

Teknik analisis data dalam penelitian ini menggunakan teknik statistik. Pengujian hipotesis dengan teknik partial least square - structural equation modeling (PLS SEM) dengan menggunakan software smartPLS 2.0. Metode PLS terdiri dari tiga tahapan: Evaluasi Inner Model, Evaluasi Outer Model, Pengujian Hipotesa. Dengan persamaan struktural:

$\mathrm{Y}=\gamma 1 \mathrm{X} 1+\gamma 2 \mathrm{X} 2+\gamma 3 \mathrm{X} 3+\gamma 4 \mathrm{X} 4+\gamma 5 \mathrm{X} 5+\zeta$

Kemampulabaan $=\gamma 1$ kualitas aset produktif $+\gamma 2$ ukuran perusahaan $+\gamma 3$ likuiditas $+\gamma 4$ kecukupan modal $+\gamma 5$ tingkat efisiensi $+\zeta$ (Zeta / tingkat kesalahan struktural)

\section{HASIL DAN PEMBAHASAN}

\section{Hasil Uji PLS SEM}

Data akan di analisis dengan menggunakan PLS SEM. Pembahasan meliputi model penelitian yang ditunjukkan dengan diagram jalur, dan pembacaan hasil analisis dengan penilaian model pengukuran (bagian luar dan bagian dalam), pengujian reabilitas komposit, pengujian reabilitas indikator, Average Variance Extracted (AVE), validitas masing-masing variabel, R Square variabel endogenus, serta estimasi nilai koefisien jalur.

Hasil uji reliabilitas terhadap masing-masing indikator dapat disimpulkan bahwa semua indikator yang digunakan dalam penelitian ini reliabel, karena semua indikator memiliki nilai diatas 0,6. Hasil pengujian validitas konvergen dengan menggunakan nilai output dari $A V E$ maka dapat disimpulkan bahwa setiap variabel laten mampu menjelaskan indikatornya, hal ini terlihat dari seluruh hasil $A V E$ bernilai diatas kriteria, yaitu 0,5 . Hasil pengujian validitas diskriminan, maka dapat disimpulkan bahwa, untuk variabel endogen/ variabel dependen yang diukur dengan indikator RoRWA dan $R O A$ yang masing-masing memiliki nilai 0,993 dan 0,994 , hal ini menunjukkan nilai cross loading indikator terhadap variabelnya lebih tinggi dibandingkan dengan variabel lainnya, sehingga indikator RoRWA dan ROA memiliki kecocokan terhadap variabel kemampulabaan. Untuk variabel eksogen/variabel independen masing-masing: kualitas aset produktif (X1) dengan indikator $N P L$, ukuran perusahaan (X2) dengan indikator Ln total aset, likuiditas (X3) dengan indikator $L D R$, kecukupan modal (X4) dengan indikator $C A R$, dan tingkat efisiensi (X5) dengan indikator BOPO masing-masing memiliki nilai 1 , sehingga dapat dikatakan bahwa masing-masing indikator memiliki kecocokan dengan variabel. Nilai $\mathrm{R}$ Square yang didapat sebesar 0,923 atau sebesar 92,3\%. Hal ini menunjukkan bahwa variabel eksogen / variabel independen yang berisi kualitas aset produktif (X1) dengan indikator $N P L$, ukuran perusahaan (X2) dengan indikator Ln total aset, likuiditas (X3) dengan indikator $L D R$, kecukupan modal (X4) dengan indikator $C A R$, dan tingkat efisiensi (X5) dengan indikator BOPO mampu menjelaskan variabilitas variabel endogen/ variabel dependen sebesar 92,3\%, sedangkan $7,7 \%$ lainnya dipengaruhi oleh variabel lainnya yang tidak dijelaskan dalam penelitian ini. 
Tabel 1. Hasil Path Coefficients

Sumber: Output SmartPLS 2.0 (2017)

\begin{tabular}{|c|c|c|}
\hline & Kemampulabaan & $\begin{array}{c}\text { Standard Error } \\
\text { (STERR) }\end{array}$ \\
\hline Kemampulabaan & & 0.035260 \\
\hline $\begin{array}{c}\text { X1 Kualitas Aset } \\
\text { Produktif }\end{array}$ & -0.025797 & 0.021723 \\
\hline $\begin{array}{c}\text { X2 Ukuran } \\
\text { Perusahaan }\end{array}$ & 0.035249 & 0.016794 \\
\hline X3 Likuiditas & -0.009693 & 0.025341 \\
\hline $\begin{array}{c}\text { X4 Kecukupan } \\
\text { Modal }\end{array}$ & 0.073552 & 0.033017 \\
\hline $\begin{array}{c}\text { X5 Tingkat } \\
\text { Efisiensi }\end{array}$ & -0.950558 & \\
\hline
\end{tabular}

$\zeta$ (Zeta) diperoleh dari hasil penjumlahan nilai pada kolom standard error. Persamaan model struktural yang dapat dihasilkan sebagai berikut:

$\mathrm{Y}=-0,25797 \mathrm{X} 1+0,035249 \mathrm{X} 2-0,009693 \mathrm{X} 3+0,073552 \mathrm{X} 4-0,950558 \mathrm{X} 5+$ 0,132135

Berdasarkan hasil Total Effects untuk original sample atas kualitas aset produktif (X1) yang diproksikan dengan NPL memiliki nilai -0,025797 yang berarti kualitas aset produktif dengan indikator $N P L$ mempengaruhi negatif kemampulabaan dengan indikator RoRWA dan ROA, sehingga Hal diterima, Hasil pengukuran T-Statistics sebesar $0,731614(<1,96)$ menunjukkan bahwa besarnya pengaruh kualitas aset produktif tidak signifikan terhadap kemampulabaan.

Berdasarkan hasil Total Effects untuk original sample atas ukuran perusahaan (X2) yang diproksikan dengan Ln Total Aset memiliki nilai 0.035249 yang berarti ukuran perusahaan dengan indikator Ln Total Aset mempengaruhi positif kemampulabaan dengan indikator RoRWA dan ROA, sehingga Ha2 diterima, Hasil pengukuran T-Statistics sebesar $1.622599(<1,96)$ menunjukkan bahwa besarnya pengaruh ukuran perusahaan tidak signifikan terhadap kemampulabaan.

Berdasarkan hasil Total Effects untuk original sample atas likuiditas (X3) yang diproksikan dengan LDR memiliki nilai -0.009693 yang berarti likuiditas dengan indikator $L D R$ mempengaruhi negatif kemampulabaan dengan indikator RoRWA dan ROA, sehingga Ha3 ditolak, Hasil pengukuran T-Statistics sebesar $1.622599(<1,96)$ menunjukkan bahwa besarnya pengaruh likuiditas tidak signifikan terhadap kemampulabaan.

Berdasarkan hasil Total Effects untuk original sample atas kecukupan modal (X4) yang diproksikan dengan $C A R$ memiliki nilai 0.073552 yang berarti kecukupan modal dengan indikator CAR mempengaruhi positif kemampulabaan dengan RoRWA dan ROA, sehingga $\mathrm{Ha} 4$ diterima, Hasil pengukuran T-Statistics sebesar $2.902470(>1,96)$ menunjukkan bahwa besarnya pengaruh kecukupan modal signifikan terhadap kemampulabaan.

Berdasarkan hasil Total Effects untuk original sample atas tingkat efisiensi (X5) yang diproksikan dengan BOPO memiliki nilai -0.950558 yang berarti tingkat efisiensi dengan indikator BOPO mempengaruhi negatif kemampulabaan dengan indikator RoRWA dan ROA, sehingga Ha5 diterima, Hasil pengukuran T-Statistics sebesar $28.790243(>1,96)$ menunjukkan bahwa besarnya pengaruh tingkat efisiensi signifikan terhadap kemampulabaan. 


\section{Diskusi}

Hasil pengujian dengan menggunakan SmartPLS 2.0 menunjukkan bahwa kualitas aset produktif dengan indikator NPL mempengaruhi negatif kemampulabaan dengan indikator-indikatornya dengan besarnya pengaruh yang tidak signifikan. Apabila nilai $N P L$ semakin tinggi, maka kemampulabaan perbankan semakin kecil. Nilai $N P L$ yang tinggi berarti total pembiayaan bermasalah dalam bank tersebut juga tinggi. Ukuran perusahaan dengan indikator $\mathrm{Ln}$ total aset mempengaruhi positif kemampulabaan dengan indikator-indikatornya dengan besarnya pengaruh yang tidak signifikan. Semakin besar aset yang dimiliki oleh sebuah perbankan dianggap dapat meningkatkan laba bank tersebut. Apabila bank dengan aset yang besar dianggap mampu untuk menyalurkan lebih banyak kredit kepada masyarakat, sehingga dari kredit tersebut didapat bunga yang dapat meningkatkan pendapatan dan kemampulabaan sebuah perbankan. Likuiditas dengan indikator LDR mempengaruhi negatif kemampulabaan dengan indikator-indikatornya dengan besarnya pengaruh yang tidak signifikan. Apabila nilai $L D R$ semakin tinggi maka tingkat laba yang dihasilkan oleh bank rendah. Dalam hal ini apabila bank tidak mampu menyalurkan kreditnya dengan baik, maka akan menimbulkan kredit macet dikemudian hari, dan akan menambah beban bagi kredit yang bermasalah tersebut serta pada akhirnya akan mengurangi laba bagi perbankan. Apabila $L D R$ naik, maka kemampulabaan akan turun. Kecukupan modal dengan indikator $C A R$ mempengaruhi positif kemampulabaan dengan indikatorindikatornya dengan besarnya pengaruh signifikan. Apabila sebuah bank memiliki modal yang lebih, maka bank tersebut dapat dengan mudah memenuhi persyaratan perbankan yang dianjurkan oleh pemerintah, sehingga kelebihan modal yang tidak digunakan dalam operasional dapat diberikan sebagai pinjaman dan menambah pendapatan bagi perusahaan yang juga meningkatkan kemampulabaan perbankan tersebut. Tingkat efisiensi dengan indikator BOPO mempengaruhi negatif kemampulabaan dengan indikator-indikatornya dengan besarnya pengaruh signifikan. Apabila bank tidak efisien dalam mengelola beban operasionalnya, maka bank tersebut tidak akan mampu untuk menghasilkan pendapatan, sehingga laba yang dihasilkan kecil atau bahkan tidak memiliki laba.

\section{KESIMPULAN DAN SARAN}

Berdasarkan hasil pengujian dengan menggunakan SmartPLS 2.0 ditunjukkan bahwa kualitas aset produktif, ukuran perusahaan, dan kecukupan modal berpengaruh positif terhadap kemampulabaan, sedangkan likuiditas dan tingkat efisiensi berpengaruh negatif terhadap kemampulabaan.

Keterbatasan dalam penelitian ini adalah sampel yang digunakan hanya pada Bank Umum Konvensional yang terdaftar di Bursa Efek Indonesia periode 2011-2016, variabel yang digunakan pada tesis ini hanya sebatas pada kualitas aset produktif, ukuran perusahaan, likuiditas, kecukupan modal, dan tingkat efisiensi.

Berdasarkan kesimpulan dan keterbatasan penelitian ini, terdapat beberapa saran yang diajukan untuk penelitian selanjutnya. Saran untuk akademisi yaitu memperpanjang periode penelitian dan menambahkan jumlah sampel untuk mendapatkan hasil yang lebih baik, menambah jumlah variabel dan indikator serta menambah model penelitian baru yang dapat dilakukan dengan menambahkan variabel moderating ataupun intervening dalam penelitian agar dapat mengetahui faktor-faktor yang mempengaruhi kemampulabaan secara tepat. Saran untuk praktisi yaitu mempertimbangkan keputusan yang akan diambil, sehingga dengan adanya keputusan yang baik, maka operasional perusahaan yang dijalankan menjadi lebih baik, namun juga dengan mempertimbangkan faktor makro ekonomi dan kondisi sosial, lingkungan, dan politik yang ada pada suatu 
daerah tertentu.

\section{Ucapan Terima Kasih}

Acknowledgement ini ditulis di bawah kesimpulan, sebelum referensi. Dalam acknowledgement ini disebutkan pihak-pihak utama yang mendukung penelitian ini, misalnya pemberi dana, instansi/orang pemberi data (dapat disamarkan apabila diperlukan anonim), asisten peneliti

\section{REFERENSI}

Akenga, G. (2015). Effect on liquidity on financial performances of firms listed at Nairobi Securities Exchanges. International Journal of Science and Research, 14 (1): 279-286.

Ali, K., Akhtar, M. F., \& Ahmed, H. Z. (2011). Bank specific and macroeconomic indicators of profitability-empirical evidance from commercial banks of Pakistan. International Journal of Business and Social Science, Vol. 2, No. 6.

Almazari, A. A. (2014). Impact of internal factors on bank profitability: Comparative study between Saudi Arabia and Jordan. Journal of Applied Finance \& Banking, Vol. 4, No. 1, 125-140.

Alper, D., \& Anbar, A. (2011). Bank specifis and macroeconomic determinants of commercial bank profitability: Empirical evidence from Turkey. Business and Economics Research journal, Vol. 2, No. 2.

Ani, W. U., Ugwunta, D. O., Ezeudu, I. J., \& Ugwuanyi, G. O. (2012). An empirical assessment of the determinants of bank profitability in Nigeria: Bank characteristics panel evidence. Journal of Accounting and Taxation, Vol. 4(3), pp. 38-43.

Bank Indonesia. (2004). Surat edaran kepada semua bank umum yang melaksanakan kegiatan usaha secara konvensional di Indonesia (Surat Edaran No. 6/23/DPNP). Jakarta: Bank Indonesia.

Bank Indonesia. (2011). Surat edaran kepada semua bank umum di Indonesia (Surat Edaran No. 13/30/DPNP). Jakarta: Bank Indonesia.

Bougatef, K. (2015). Determinants of bank profitability in Tunisia: Does corruption matter? Journal of Money Laundering Control, Vol. 20, Issue: 1, pp.70-78.

Brie, L., \& Freon, H. (2016). RWA Density | What lies behind this underrated financial ratio. Global Research \& Analytics.

Duraj, B., \& Moci, E. (2015). Factors influencing the bank profitability - empirical evidence from Albania. Romanian Economic and Business Review, Vol. 10, No. 1.

Idris, A. R., Asari, F. F. A. H., Taufik, N. A. A., Salim, N. J., Mustaffa, R., \& Jusoff, K. 2011. Determinant of islamic banking institutions' profitability in Malaysia. World Applied Sciences Journal 12 (Special Issue on Bolstering Economic Sustainability), Hal. 1-7.

Ikatan Bankir Indonesia (IBI), \& Banker Association for Risk Management (BARa). (2016). Manajemen kesehatan bank berbasis risiko (1st ed.). Jakarta: PT Gramedia Pustaka Utama.

Javaid, S., Anwar, J., Zaman, K., \& Goafoor, A. (2011). Determinants of bank profitability in Pakistan: Internal factor analysis. Mediteranean Journal of Social Sciences, Vol. 2, No. 1.

Kasmir, S.E., MM. 2010. Manajemen Perbankan. Jakarta: Rajawali Press.

M., Ralona. 2006. Kamus Istilah Ekonomi Populer. Jakarta: Gorga Media.

Malhotra, N. K. (2004). Marketing Research: An Applied Orientation (4th ed.). New Jersey: Prentice Hall. 
Menicucci, E., \& Paolucci, G. (2015). The determinants of bank profitability: Empirical evidence from European banking sector. Journal of Financial Reporting and Accounting, Vol. 14, Issue: 1, pp.86-115.

Merin, M. A. (2016). Determinants of bank profitability in Ethiopia: A case study of private commercial banks. Research Journal of Finance and Accounting, Vol. 7, No.7.

Muhamet, A., \& Arbana, S. (2016). The effect of credit risk management on banks' profitability in Kosovo. European Journal of Economic Studies, Vol. 18, Is. 4, pp. 492-515.

Ongore, V. O., Kusa, G. B. (2013). Determinants of financial performance of commercial banks in Kenya. International Journal of Economics and Financial Issues, Vol. 3, No. 1, pp. 237-252.

Otoritas Jasa keuangan Republik Indonesia. (2017). Kewajiban penyusunan dan pelaksanaan kebijakan perkreditan atau pembiayaan bank bagi bank umum (Salinan Peraturan Otoritas Jasa Keuangan Nomor 42/Pojk.03/2017). Jakarta: Dewan Komisioner Otoritas Jasa Keuangan.

Petria, N. et al. 2015. Determinants of banks' profitability: evidence from EU 27 banking systems. Procedia Economics and Finance, Vol. 20, Hal. 518-524.

Rahman, S. U., Jan, F. A., Iqbal, K., \& Ali, Z. (2012). Parameter of convensional and islamic bank's profitability in Pakistan: evaluation of internal factor. Research Journal of Finance and accounting, Vol. 3, No. 3.

Ramadan, I. Z., Kilani, Q. A., \& Kaddumi, T. A. (2011). Determinant of commercial banks performance: Evidance from Jordan. International Journal of Academic Research, Vol. 3, No. 4.

Riaz, S., \& Mehar, A. (2013). The impact of bank specific and macroeconomic indicators on the profitability of commercial banks. The Romanian Economic Journal, Year XVI, No. 47.

Samad, A. (2015). Determinant bank profitability: Empirical evidence from Bankladesh commercial banks. International Journal of Financial Research, Vol. 6. No. 3.

Sarwono, J., \& Narimawati, U. (2015). Membuat skripsi, tesis dan disertasi dengan Partial Least Square SEM (PLS SEM). Yogyakarta, C.V Andi Offset (Penerbit ANDI).

Schiniotakis, N. I. (2012). Profitability factors and efficiency of Greek banks. EuroMed Journal of Business, Vol. 7, Issue: 2, pp.185-200.

Sekaran, U., \& Bougie, R. (2016). Research method for business: A Skill Building Approach (7th ed.). New York: John Wiley \& Sons, Inc.

Siallagan, H., \& Machfoedz, M. 2006. Mekanisme corporate governance, kualitas laba dan nilai perusahaan. Simposium Nasional Akuntansi IX. Padang.

Sinn, W., D’Acunto, R., \& Oldrini, A. (2013). European banking: Striking the right balance between risk and return. Bain Report. Retrieved from http://www.bain.com/publications/articles/european-banking-bain-report.aspx

Siregar, S. 2013. Metode penelitian kuantitatif. Jakarta: PT Fajar Interpratama Mandiri.

Sitepu, A. C., \& Siregar, H. S. (2007). Faktor-faktor yang mempengaruhi pengungkapan informasi sosial dalam laporan tahunan pada perusahaan manufaktur yang terdaftar di Bursa Efek Jakarta. Universitas Sumatera Utara.

Syafri. (2012). Factors affecting bank profitability in Indonesia. The 2012 International Conference on Business and Management.

Tan, Y., Floros, C., \& Anchor, J. (2016). The profitability of Chinese banks: Impacts of risk, competition and efficiency. Review of Accounting and Finance, Vol. 16, Issue: $1, \mathrm{pp} .86-105$. 
Taswan. (2005). Akuntansi Perbankan. Transaksi Dalam Valuta Rupiah (1st ed), Yogyakarta: UPP AMP YKPN.

Undang-Undang Republik Indonesia Nomor 7 Tahun 1992 Tentang Perbankan Sebagaimana Telah Diubah Dengan Undang-Undang Nomor 10 Tahun 1998 Tentang Perbankan.

Veithzal, R. dkk. (2013). Manajemen perbankan dari teori ke praktik. Jakarta: PT. Raja Grafindo Persada.

Yamuna, S. (2013). Determinants of profitability in the banking sector: A study with special reference to private commercial banks in Sri Lanka. Proceedings of the Third International Symposium, SEUSL: 6-7.

http://www.bi.go.id/id/kamus.aspx?id=k

http://www.ojk.go.id/id/kanal/perbankan/regulasi/undang-undang/pages/undang-undangnomor-7-tahun-1992-tentang-perbankan-sebagaimana-diubah-dengan-undangundang-nomor-10-tahun-1998.aspx 